\title{
THE IMPACT OF HYBRID ENGINES ON FUEL CONSUMPTION AND EMISSIONS OF HEAVY-DUTY TRUCKS
}

\author{
FRANS BAL \& JAAP VLEUGEL \\ RISSK \& Faculty of Civil Engineering \& Geosciences, Delft, The Netherlands
}

\begin{abstract}
Overland transport of goods mainly goes by road. Road freight transport, trucking in particular, has a large share in the energy consumption, $\mathrm{CO}_{2}$-emissions and air pollution by human activities. This will become an even bigger issue with the expected massive growth of road freight transport. Climate change mitigation asks for a major reduction of $\mathrm{CO}_{2}$-emissions from human origin. Improvement of air quality is a second reason why trucking companies have to look for alternative engine-fuel configurations: Biodiesel, gas and electricity. The paper answers two research questions: New truck technologies are under way, what impact could these have on fuel consumption and emissions related with the fuel consumption of trucks? How realistic is large-scale introduction of these new technologies before the year 2030? A model was used to estimate the emissions of $\mathrm{CO}_{2}$, $\mathrm{NO}_{\mathrm{x}}$ and $\mathrm{PM}_{10}$ of a truck transporting goods along a pre-defined route consisting of city roads and highways. The volumes and composition of the emissions vary depending on the data entered by the user: Route/distance, fuel efficiency/consumption, emission factors and engine-fuel configuration. The model was used for a micro-simulation, but an extension towards a macro-simulation model is feasible. This would allow to estimate the impact on fuel consumption and emissions for a fleet of trucks. The model indicates that the main benefit of an alternative like biodiesel lies in the reduction of PM10-emissions. Electric trucking is necessary to drastically reduce $\mathrm{CO}_{2}$-emissions and air pollution. In a few years from now hybrid diesel-electric trucks will become common. Full-electric trucks energized by internal (hydrogen in fuel cells) and/or external (trolley-like, high density batteries) sources are feasible well before the year 2030. Electric trucking means a drastic change in the use of fuels with implications for the electricity grid as well.
\end{abstract}

Keywords: energy consumption, emissions, heavy-duty trucks, environment, conditions.

\section{INTRODUCTION}

Freight transport is an essential economic activity; hardly any human activity can do without it. Volume-wise it is already enormous and also expanding rapidly, e.g. by more than 70\% between 1990 and 2015 in EU-25 (Fig. 1). This trend can be explained by interplay of demographic, economic, logistic and transport-technical factors:

- A rapidly growing world population, partially young, which corresponds with a high population growth and a growing demand for goods, services, infrastructure, buildings etc., which stimulates growth in GDP;

- Growing political and economic linkages between countries allow a division of labour and a global spread of manufacturing;

- Consumer demand has become globally sourced;

- Businesses outsourcing production to low cost countries;

- Technical means, like containers, allowing seamless transport on a world scale. 


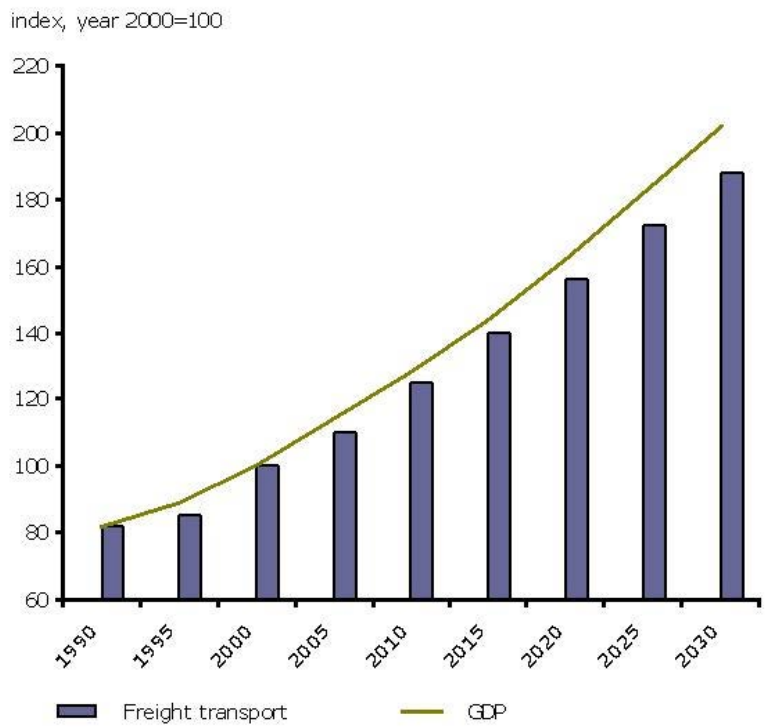

Figure 1: Growth of freight transport activity in EU-25 [1].

Road transport is dominating within and between (neighbouring) countries. More than six billion tonne-kilometres were transported by road in the EU, USA, CIS, China and Japan in 2016. In the EU, road freight transport had a market share of $50 \%$ in 1970 , which grew to $75 \%$ today [2]. These market shares differ per country, transport distance, goods category and the availability of efficient and cost-effective alternatives: barges, railways or pipeline.

Many factors make road transport so dominant. One is the shift in industry structure where local manufacturing of mass-produced heavyweight products was largely transferred to low-wage countries [3]. These countries also produce many of the consumer goods imported by developed countries, which are of the lightweight high value category. The first used to be carried mainly by rail and barge, while the latter are mainly carried by road. Accessibility is another, major, logistic factor. Road transport offers door-to-door services via a high-density network to nearly every location, unlike barge or rail. It is very flexible (routes, time), practical to organize and faster than rail, although rising road congestion reduces this benefit. Short distance barge or rail services are rare, unless very large volumes are transported on a regular basis [4]. Logistic service providers favour rail and barge where trucking is not economical or practical: for long distances (700 kilometres or more) and large volume transport. Trucks are then used to ship goods between intermodal terminals and producers or customers.

Road transport has a substantial fuel consumption, contribution to climate change and air pollution. In 2007, global final energy use was around 350 Exajoule (EJ). Transport used 96 EJ (27.7\%). Road transport (freight and passenger together) accounted for more than $70 \%$ (or nearly $70 \mathrm{EJ}$ ). Since 1970 energy use by transport has grown exponentially (Fig. 2). This growth matches the growth of global transport since that year. The $96 \mathrm{EJ}$ equals 6.6 Gigaton (Gt) of $\mathrm{CO}_{2}$ [5]. Between 1990 and 2015 the $\mathrm{CO}_{2}$-emissions of the transport sector grew by $60 \%$. By 2030 the transport sector might even have doubled its $\mathrm{CO}_{2}$-emissions compared to 1990 [6]. 


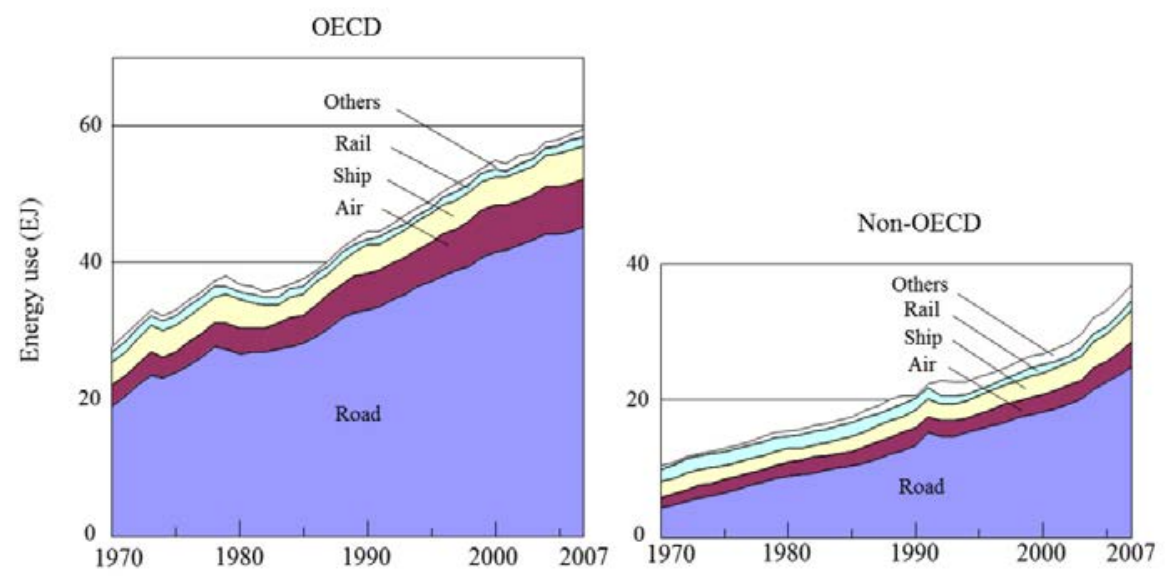

Figure 2: Transport energy use in OECD and non-OECD countries by mode [5].

This source does not contain a split into passenger and freight transport, or from the latter into trucks, heavy and light duty vehicles. Trucks consumed 500 Mtoe (21 EJ) or 23\% of the total energy consumption by the transport sector in the year 2005 [7]. It is unclear if this percentage has changed over time, but the number is indicative of its size.

Before a truck owner invests in a truck (fleet), he or she will compare different enginefuel combinations. Fuel-efficient trucks reduce the fuel bill. The environment would benefit if the chosen truck also emits less harmful substances. By comparing several of these combinations, a picture emerges of the potential reductions in fuel consumption and emissions if an optimal set of technologies would be used in a truck.

The following questions will be addressed:

1. New truck technologies are under way, what impact could these have on fuel consumption and emissions related with the fuel consumption of trucks?

2. How realistic is large-scale introduction of these new technologies before the year 2030 ?

The research includes improved or new engine/fuel combinations for heavy-duty road trucks. Policies like a partial shift to rail or barge are not in the scope. The logistic consequences of the alternative truck technologies will be added where supportive.

The geographic region will be Europe, more particular the Netherlands and Germany. This reduces the complexity related with the many different truck types, their applications, fuel infrastructures and legislation around the world. The on-going European harmonization effort gave European trucking companies common technical standards and in economic terms a level playing field. This allows these trucking companies to easily cross borders and use a large network of nearly identical fuel stations.

The time horizon should allow a partial upgrading or replacement of the truck fleet and the fuel infrastructure in line with regular technical - or investment policies for such facilities. The year 2030 may provide adequate time to do so.

Tools used in the research for this paper included desk research, scenarios as input for a simulation model, and finally (quantitative) evaluation. 


\section{THE SYSTEM AND THE PROBLEM}

This section introduces the pros and cons of diesel technology, followed by the technical challenges to manage fuel consumption and emissions of trucks.

\subsection{Truck fuels and engine technologies}

Trucks exist in different sizes, from small light-duty vehicle to articulated heavy-duty vehicles. Most heavy-duty trucks use diesel fuel in Europe. Truck owners prefer diesel engines because of their superior performance. Diesel has a higher energy density than petrol (gasoline/Otto) $\left(41 \times 10^{6}-35 \times 10^{6}\right.$ joules) [8]. But, diesel engines have a less efficient cycle. This is compensated by a much higher compression ratio (2:1 versus 9:1), made possible since diesel cannot knock like petrol. The higher compression contributes to a $30-35 \%$ higher thermal efficiency. The benefits of diesel explain the lack of petrol equivalents for these big diesel engines.

Diesel is combusted (turned into gas) after auto-ignition. There is no vacuum during the intake stroke, which allows unthrottled operation; a truck starts moving if the brakes are released. Combustion is leaner; hence combustion temperature is lower and there is less heat loss than in a petrol engine [9].

\subsection{Fuel consumption of trucks}

A heavy-duty truck is a logistic service vehicle. As a result, its fuel consumption depends on technical-, logistic- and external-factors, as follows [10]:

- Technology: vehicle specs, engine efficiency, rolling resistance, drag, brakes;

- Logistics: supply chain characteristics, routing, vehicle use, speed;

- External factors: drive speed, elevation, congestion, weather and driver.

There are three ways to calculate or estimate fuel consumption of a truck [11]:

1. A direct and most reliable way is to use fuel bills or measured fuel consumption from a truck owner's administration;

2. An alternative is to have a distance in vehicle kilometres and multiply this with average fuel consumption from a public source;

3. In case of outsourced transport, it is preferable to replace vehicle kilometres by logistics parameters like ton-kilometres and average transport distances. Average fuel consumption may vary considerably per logistic branch, load factor and $\%$ of empty driving, though. This makes this method very imprecise.

The basis for the calculations is thus very relevant if a source mentions a ratio/range of $\mathrm{x}$ litres per y km (e.g., 1:3-1:3,5 for an average truck weight of 33 metric tons running on diesel in [12]). Actors mentioned under 1 and 3 were not part of the study. Method 2 was used in this paper.

\subsection{Emissions, regulations and technology}

Combustion of fossil fuels produces emissions of $\mathrm{NO}_{x}, \mathrm{PM}, \mathrm{N}_{2} \mathrm{O}$ and $\mathrm{SO}_{2}$, and greenhouse gases $\left(\mathrm{CO}_{2}\right.$ or equivalent). 
In the past decades exhaust emission standards have been introduced in most parts of the world. Europe has the Euro emission standards for steady state and transient testing (for diesel and gas engines) [13].

New trucks have to conform to Euro VI. A comparison with Euro V indicates a major reduction in most emission categories if all technologies do what they are supposed to (see also section 2.5). Since Euro I (in 1992) emissions of CO have been reduced by $66 \%$, HC by $89 \%$, NOx by $95 \%$ and PM by $97 \%$. The non-linear tightening of these standards signals the technical challenges and (political) resistance by truck producers against them.

The Diesel gate scandal [14] could lead to doubts regarding these standards. Emissions of diesel passenger cars stayed the same in the past 2 decades, regardless of tighter standards. For instance, $\mathrm{NO}_{\mathrm{x}}$-emissions are 5-6 times higher than declared by manufacturers [15]. This points to a legislative vacuum. There exists a major difference between emissions tests for passenger cars and trucks. Producers of trucks have to prove that their engines fulfil these standards, before they are allowed on the road. The test regime for trucks has also changed with the introduction of Euro VI, while the emission durability kilometres were increased as well.

Producers of new trucks have achieved the Euro VI/6 emission targets. As a consequence, modern trucks are relatively clean as far as these emissions are concerned [15]. It took a major technical effort to get there. Technical development followed two competing routes. Most manufacturers went for SCR to reach Euro IV/V. $\mathrm{SCR}$ is a selective (urea) catalyst system that uses AdBlue (AUS32) to convert $\mathrm{NO}_{\mathrm{x}}$ via a reaction with $\mathrm{NH}_{3}$, into $\mathrm{H}_{2} \mathrm{O}$ and $\mathrm{N}_{2}$. Others went for EGR (Exhaust gas recirculation; e.g. by using turbo chargers) plus PM-KAT (catalyst to remove particulates). Nearly sulphur-free diesel was introduced for effective catalytic treatment of exhaust emissions in Euro VI [16].

A key challenge when developing these new technologies is to reduce fuel consumption and emissions. There is no trade-off.

\subsection{Challenges, incentives and caveats}

The impact of new improved/new fuel/engine configurations depends on the following factors:

- There are after-market solutions for existing truck engines. However, the biggest impact on fuel consumption and emissions should be expected from new trucks engines that are designed for maximum fuel economy and emission reduction. This implies that the pace of fleet replacement becomes important. It takes on average 7 or more years to replace a truck in The Netherlands and similar countries. Replacement depends on business-economic opportunities, depreciation practices and regulatory stimuli.

- Regulatory stimuli for innovation are regulations (e.g., the Euro standards, environmental bans for non-compliant trucks) and economic instruments (subsidies for automotive R\&D and differential taxation).

- Another stimulus is the increasing awareness in business [17], that sustainable behaviour is inevitable and also pays off. Companies with transport needs ('shippers') may select a trucking company according to its 'green' performance. Finally, competition is very tough. Fuel costs are an important cost factor; hence it pays off if trucking companies buy more fuel-efficient trucks and if truckers drive as fuel-efficient as possible. Finally, people living in densely populated areas (city 
centres) or near main roads and pedestrians appreciate a reduction in emissions and vehicle noise (e.g. due to electric trucks).

- The impact of exhaust gas emissions crucially depends on the efficiency of the catalytic converter. This is not very effective if a truck is used in city traffic only. It works properly on highways, though [15].

\subsection{Diagnosis}

Technical innovation enabled a major reduction in emissions and improved fuel efficiency (new engines, tyres, lighter materials, etc.) in the latest truck generations.

A growth of freight transport translates into more trucks and truck movements. Euro VI/6 regulates new trucks, not the older Euro classes, which are less fuel-efficient and more polluting. It takes about 7 years to replace a truck in a The Netherlands [18] and similar European countries. This means that it may take at least a decade to achieve a measurable impact in all trucks on the road.

Many countries in the world have signed the Kyoto Protocol and its follow-ups, which call for a drastic reduction of GHG-emissions from fossil fuel consumption [19]. There is also the OECD initiative, which calls for green growth [20].

Is green growth of trucking a real option? The share of the transport sector in GHGemissions rose from 15 to $23 \%$ between 1990 and 2015 [21]. This suggests that the answer may be 'considerably doubtful', which illustrates the seriousness of the macro problem.

\section{NEXT GENERATION ENGINE-FUEL ALTERNATIVES}

The truck market in Europe is dominated by diesel from fossil origins. Could society and the environment benefit from a switch to alternatives?

\subsection{A model}

A MS ${ }^{\odot}$ Excel $^{\odot}$ model was used to estimate the fuel consumption and emissions of different fuel-engine combinations in a specific scenario.

The model consists of several modules. The following are the most important:

- A module to enter scenario data. A scenario describes an origin-destination pair (transport link) in kilometres, the mode of transport, engine technology, energy category (diesel, alternative) and fuel specification (fuel-blend), electricity composition (grey, green);

- Tables with fuel consumption and emission factors (EF);

- An output module to present the results of the simulation.

The model estimates the fuel consumption by a truck with a chosen engine-fuel combination over a specified transport distance (link) by multiplying the kilometres driven with the average fuel consumption per kilometre (different per road type/section). This is then multiplied by a set of emission factors, which gives the emissions of $\mathrm{CO}_{2}, \mathrm{NO}_{\mathrm{x}}$ and $\mathrm{PM}_{10}$ of the fuel consumed during this simulated trip.

Data from academic and professional sources was used. It was very difficult to find reliable public fuel consumption data and emission factors, in particular for alternative fuels. Technology is under development and competitive stress leads to secrecy by suppliers. In some cases, only part of input data could be found. This is reflected in Tables 3 and 4. 


\subsection{Scenarios and results}

Everyday many trucks transport goods between the port of Rotterdam (The Netherlands) and the German Ruhr area. The following scenario is realistic: A regular truck-trailer combination starts with a round-trip in Rotterdam to pick up goods, and then goes to Duisburg for a drop-off. The trip is around 206 kilometers one-way. Intermediate stops at truck parks or tank stops were left out to simplify the estimations.

A Euro VI truck-trailer combination uses around 59 liters of diesel to capture this distance. This leads to the following emissions (Table 1).

Many different combinations of engines and fuels are theoretically interesting. The ones initially considered can be found in Table 2, the selected ones in Table 3. Some alternative fuels can be used in (modified) existing engines: Biodiesel (B100), CNG and LPG. Biodiesel is usually added to regular diesel to make a blend. B100 (100\% biodiesel) is used to study the limits of technology. The environmental performance of this fuel depends strongly on the source (there are different generations of organic and synthetic nature).

$\mathrm{CNG} / \mathrm{LNG}$ is regularly used in city buses. The lack of a fuel station network is not an issue. LPG is a regular fuel for passenger cars and vans, but not for heavy-duty trucks.

Full-electric trucks are used in city logistics, but they are not ready for long distance trips yet, due to the limited range of current batteries [22] and the lack of charging facilities for trucks (along highways). An experiment may change this; a trolley-like power line is used to power electric trucks on a highway test section in Germany [23].

Trucks with hydrogen in fuel cells are used in road tests in the USA [24]. Hydrogen is produced on a large-scale in industrial applications, but there is no network of fuel stations. Countries like Japan and Germany are developing these [25], though. Large-scale electrification of trucking is regarded as very likely [26].

Table 1: Estimated truck-trailer emissions (regular diesel).

\begin{tabular}{|l|c|c|c|c|c|c|}
\hline & $\mathrm{CO}_{2}$ & $\%$ & NOx & $\%$ & PM10 & $\%$ \\
\hline Departure time x & & & & & & \\
\hline Rotterdam local & 3352 & 2.2 & 14.7 & 2.2 & 3.4 & 2.2 \\
\hline No stop & & & & & & \\
\hline Rotterdam ring road & 1696 & 1.1 & 7.0 & 1.1 & 1.7 & 1.1 \\
\hline No stop & & & & & & \\
\hline Highways & 142642 & 90.3 & 592.1 & 90.3 & 138.9 & 90.3 \\
\hline No stop & & & & & & \\
\hline Duisburg ring road & 8056 & 5.1 & 33.4 & 5.1 & 7.8 & 5.1 \\
\hline No stop & & & & & & \\
\hline Duisburg local & 2018 & 1.3 & 8.4 & 1.3 & 2.0 & 1.3 \\
\hline Arrival time y & & & & & & \\
\hline Total (grams) & 157944 & 100 & 656 & 100 & 154 & 100 \\
\hline
\end{tabular}

Note: All emissions are in grams, based on tank-to-wheel (TTW). 
Table 2: Estimated truck-trailer emissions (all options).

\begin{tabular}{|l|l|c|c|c|}
\hline Route scenario & Type & $\mathrm{CO}_{2}{ }^{1)}$ & $\mathrm{NO}_{\mathrm{x}}$ & $\mathrm{PM}_{10}$ \\
\hline \multirow{5}{*}{ Rotterdam-Duisburg } & Regular diesel & 157944 & 656 & 154 \\
\cline { 2 - 5 } & B100 Diesel & 148468 & 715 & 46 \\
\cline { 2 - 5 } & $\mathrm{CNG}$ & 140664 & No data & No data \\
\cline { 2 - 5 } & LPG & No data & No data & No data \\
\cline { 2 - 5 } & LNG & 156480 & No data & No data \\
\cline { 2 - 5 } & Hydrogen ${ }^{2)}$ & 0 & 0 & 0 \\
\cline { 2 - 5 } & FEV (grey grid) & 190436 & 157 & 13 \\
\cline { 2 - 5 } & FEV (green grid) & 0 & 0 & 0 \\
\hline
\end{tabular}

Notes:

1) All emissions are in grams, based on tank-to-wheel (TTW).

2) If produced from green sources, and TTW only.

Table 3: Estimated emissions: Diesel versus hybrid.

\begin{tabular}{|c|c|c|c|c|}
\hline & Type & $\mathrm{CO}_{2}$ & $\mathrm{NO}_{\mathrm{x}}$ & $\mathrm{PM}_{10}$ \\
\hline \multirow{2}{*}{$\begin{array}{l}\text { TEN } \\
\text { Rotterdam- } \\
\text { Duisburg }\end{array}$} & Regular diesel & 153008 & 635 & 149 \\
\hline & B100 Diesel & 143828 & 692 & 45 \\
\hline \multirow{5}{*}{$\begin{array}{l}\text { "Electric } \\
\text { highway" } \\
\text { Rotterdam- } \\
\text { Duisburg }\end{array}$} & Diesel + electric drive NL/Grey grid & 186810 & 204 & 17 \\
\hline & Diesel + electric drive G/Grey grid & 173734 & No data & No data \\
\hline & Diesel + electric drive Green grid & 14824 & 62 & 14 \\
\hline & B100 + electric drive NL/Grey grid & 185921 & 209 & 7 \\
\hline & B100 + electric drive Green grid & 13935 & 67 & 4 \\
\hline
\end{tabular}

Note: All emissions are in grams, based on tank-to-wheel (TTW).

\subsection{Evaluation}

Table 4 illustrates that a shift from regular diesel to biodiesel has a limited impact on $\mathrm{CO}_{2}$ emissions. Emissions of $\mathrm{NO}_{\mathrm{x}}$ may even rise. The real benefit lies in the reduction of $\mathrm{PM}_{10}$. Use of HEV or FEV with green electricity from the grid ('electric highway' solution) will reduce the emissions due to (long haul) mobility drastically. The greener energy mix from the Germany grid (G/grey grid already leads to a $7 \% \mathrm{CO}_{2}$ reduction compared to the grey NL grid. The NL grid itself will become greener due to the rising import and local production of green energy. A greener grid means fewer emissions by electric vehicles powered by it.

\section{CONCLUSIONS}

A model was used to for a micro-simulation in order to estimate the impact of new enginefuel configurations. These tend to have a mixed impact on fuel consumption and emissions of $\mathrm{CO}_{2}, \mathrm{NO}_{\mathrm{x}}$ and PM10 of a truck transporting goods along a pre-defined route consisting of city roads and highways. The main benefit of an alternative power source like biodiesel 
lies in the reduction of PM10-emissions. A shift to electric trucking is necessary to substantially reduce all emissions.

In a few years from now hybrid diesel-electric trucks will become common. Full-electric trucks energized by internal (hydrogen in fuel cells) and/or external (trolley-like, high density batteries) sources are feasible well before the year 2030. Yet another alternative is hydrogen in fuel cells. Electric driving would mean a drastic change in the use of fuels with major implications for the grid as well.

Enablers for these changes are a large-scale alternative fuel network, a competitive price and reliable performance of engines. Many stakeholders are working to establish these conditions.

An extension of the model would allow macro-simulations, for instance to estimate the fuel consumption and emissions of a fleet of trucks equipped with alternative engine-fuel configurations.

\section{REFERENCES}

[1] European Environment Agency, Freight transport activity growth for EU 25, www.eea.europa.eu/data-and-maps/figures/freight-transport-activity-growth-for-eu25, Copenhagen, 2010.

[2] Eurostat, Energy, transport and environment indicators, 2016 edition, Luxembourg, 2016.

[3] OECD, Decoupling the Environmental Impacts of Transport, www.oecd.org/ greengrowth/greening-transport/37722729.pdf.

[4] An example is transport of export beer between Heineken's brewery in Zoeterwoude and the port of Rotterdam. It saves $7.3 \mathrm{mln}$ truckkms (85\%) yearly, www.ttm.nl/nieuws/heineken-shift-bier-van-truck-naar-binnenvaart/9006/.

The engines of the barges (partially) run on biofuel as well.

[5] IIASA, Energy End-Use: Transport, www.iiasa.ac.at/web/home/research/FlagshipProjects/Global-Energy-Assessment/GEA_Chapter9.pdf.

[6] Eurostat, Greenhouse gas emission statistics, http://ec.europa.eu/eurostat/statisticsexplained/index.php/Greenhouse_gas_emission_statistics, 2017.

[7] Kojima, K. \& Ryan, L., Transport Energy Efficiency, IEA, Paris, 2010.

[8] Brain, M., How Diesel Engines work, auto.howstuffworks.com/diesel3.Htm.

[9] Regueiro, A., Why is the thermal efficiency of diesel engines higher than that of Petrol Engines, www.quora.com/Why-is-the-Thermal-Efficiency-of-Diesel-Engineshigher-than-that-of-Petrol-Engines.

[10] Odhams, A.M.C., Roebuck, R.L., Hunt, S.W. \& Cebon, D., Factors influencing the energy consumption of road freight transportation, Proc. IMechE 224 Part C: J. Mechnical Engineering Science, 2004, DOI: 10.1243/ 09544062JMES2004, 2009.

[11] VIL, Meten is weten - het berekenen van C2-emissies, http://vil.be/2013/ meten-isweten/\#, 2013.

[12] Bosman, P., Het gemiddeld gebruik van een vrachtauto, Google+, http://gemiddelden.nl/verbruik/gemiddeld-verbruik-van-een-vrachtauto, 2017.

[13] Dieselnet, EU: Heavy-duty truck and bus engines, www.dieselnet.com/ standards/eu/hd.php.

[14] Smith, G., Volkswagen's Dieselgate Scandal Just Got Bigger, fortune.com /2016/11/07/vw-dieselgate-more-bad-news/, November 07, 2016.

[15] Dijkhuizen, B., TNO: Euro 6 trucks sneller schoon dan nieuwe dieselauto's, Vakmedianet, 8 June 2015. See also ICCT, A technical summary of Euro 6/VI 
vehicle emission standards, www.theicct.org/sites/default/files/ publications/ICCT_Euro6-VI_briefing_jun2016.pdf.

[16] Erkkila, K., Nylund, N-O., Fuel efficiency of new European HD vehicles, DEER 2007 Conference, Detroit, Michigan, 12-16 Aug 2007.

[17] The successful Lean \& Green program is an example in The Netherlands and Belgium, www.globalreporting.org/network/report-or-explain/campaign-forummembers/ Pages/Connekt---Lean-and-Green.aspx.

[18] ING Bank, Trucks en trailers, Truck- en trailermarkt in teken van optimalisatie, www.ing.nl/media/20150317\%20ING\%20Assetvie\%20Truck-

$\% 20$ en $\% 20$ trailermarkt $\% 20$ in\%20teken\%20van\%20optimalisatie_tcm162-81579 .pdf.

[19] UN, The Paris Agreement, unfccc.int/paris_agreement/items/9485.php.

[20] OECD, Green Strategy Synthesis Report: Towards Green Growth, www.oecd.org, May 2011.

[21] Eurostat, Greenhouse gas emission statistics, ec.europa.eu/eurostat/statisticsexplained/index.php/Greenhouse_gas_emission_statistics, 2017.

[22] TTM, Eerste 40 tons elektrische truck ingezet door BMW, https://www.ttm.nl/nieuws/eerste-40-tons-elektrische-truck-ingezetdoor-bmw/ $72870 /$.

[23] eHighway - Electrification of road freight transport, www.siemens.com/ global/en/home/products/mobility/road-solutions/electromobility/ehighway.html.

[24] Waterstof op weg, De Ingenieur 1, p. 49, 2017.

[25] Reformatorisch Dagblad, Shell bouwt waterstofstations in Duitsland, www.refdag.nl/nieuws/anp/economie/shell_bouwt_waterstofsta/ons_in_duitsland_1_ 945796, 13 Oct 2015.

[26] Navigant Research, Global Annual Sales of Electric Trucks are Expected to Reach 332,000 by 2026, www.navigantresearch.com/newsroom/global-annual-sales-ofelectric-trucks-are-expected-to-reach-332000-by-2026. 